\title{
Effectiveness of Asteraceae extracts on Trichostrongylidae eggs development in sheep
}

\author{
Eficácia de extratos da família Asteraceae no desenvolvimento dos ovos de Trichostrongilídeos de ovinos
}

Silvana Krychak-Furtado ${ }^{1 *}$; Ana Luisa Palhano Silva ${ }^{1}$; Obdulio Gomes Miguel²; Josiane de Fátima Gaspari Dias ${ }^{3}$; Marilis Dallarmi Miguel ${ }^{3}$; Sonia Soares Costa ${ }^{4}$; Raquel Rejane Bonato Negrelle ${ }^{5}$

\begin{abstract}
${ }^{1}$ Curso de Medicina Veterinária, Faculdade de Ciências Biológicas e da Saúde - FCBS, Universidade Tuiuti do Paraná - UTP
${ }^{2}$ Laboratório de Fitoquímica, Departamento de Farmácia, Programa de Pós-Graduação em Ciências Farmacêuticas, Universidade Federal do Paraná - UFPR

${ }^{3}$ Laboratório de Farmacotécnica, Departamento de Farmácia, Programa de Pós-Graduação em Ciências Farmacêuticas, Universidade Federal do Paraná - UFPR

${ }^{4}$ Núcleo de Pesquisas de Produtos Naturais, Universidade Federal do Rio de Janeiro - UFRJ

${ }^{5}$ Laboratório OIKOS, Departamento de Botânica, Universidade Federal do Paraná -UFPR
\end{abstract}

Received December 14, 2010

Accepted March 4, 2011

\begin{abstract}
Data on in vitro evaluation of extracts of three species of the Asteraceae family on the development of Trichostrongylidae eggs in sheep are presented. Egg hatchability was tested using herbal extracts prepared in a Soxhlet extractor, and using hydrolate prepared by means of hydrodistillation. The laboratory tests showed that the ethanol extract from flowers of the species Aster lanceolatus presented high activity against Trichostrongylidae eggs development in sheep, inhibiting larva formation by $91 \%$ within 48 hours, and maintaining similar rates after 72 hours.
\end{abstract}

Keywords: Asteraceae, parasites, anthelmintic, phytotherapeutics.

\section{Resumo}

Apresentam-se dados da avaliação in vitro de três espécies vegetais da família Asteraceae sobre o desenvolvimento dos ovos de Trichostrongilídeos de ovinos. Realizou-se o teste de eclodibilidade com extratos vegetais preparados por aparelho de Soxhlet e hidrolato preparado por hidrodestilação. Os testes laboratoriais evidenciaram que o extrato etanólico das flores da espécie Aster lanceolatus apresenta alta atividade sobre o desenvolvimento dos ovos de Trichostrongilídeos de ovinos, inibindo em $91 \%$ a formação da larva em 48 horas, mantendo-se índices próximos em 72 horas.

Palavras-chave: Asteraceae, parasitas, anti-helmíntico, fitoterápicos.

\section{Introduction}

Most sheep flocks are infected with Trichostrongylidae that has high tolerance to chemotherapy. This gives rise to yield losses, not only both because of the support treatments that the infected animals need and increased manpower needs, but also especially because of the consequences of the high mortality rate within flocks (VAN WYK; MALAN, 1988; ECHEVARRIA et al., 1996).

The problematic resistance presented by nematodes to anthelmintics is a matter of worldwide concern (WALLER, 1994). Selection of species that are resistant to several types of anthelmintics may be attributed to intensive use of these products,

\footnotetext{
*Corresponding author: Silvana Krychak-Furtado

Curso de Medicina Veterinária,

Faculdade de Ciências Biológicas e da Saúde - FCBS,

Universidade Tuiuti do Paraná - UTP, Rua Comendador Pinto Bandeira,

167-A, CEP 81530-350, Curitiba - PR, Brazil;

e-mail: silvana.krychak@pop.com.br; silvana.krychak@utp.br
}

underdosing or handling problems (RAMOS et al., 2002). Species of the family Trichostrongylidae originating from sheep, which were resistant to levamisole, ivermectin, and albendazole, were found in the state of Santa Catarina, in Brazil (RAMOS et al., 2002), and some species resistant to oxfendazole, levamisole and ivermectin were found in the state of Ceará (MELO et al., 2003).

Another problem in using chemical products to control parasites is the impact on the environment. There is a need to search for other, efficient parasite control methods, since the harm caused by parasitosis makes animal production impracticable (MARI; FIEL, 1992). Thus, among the new alternatives for controlling helminthiasis in sheep, one option investigated has been to identify phytotherapeutics with anthelmintic action (JACKSON, 1993; WALLER et al., 1995; HERD, 1996; VIEIRA, 2004).

In these investigations, the criteria used to select plant species were their availability and/or easy obtainment, the environmental 
impact that their use would cause (CUNNINGHAM, 2001) and the existence of other studies relating to their biological activity.

The first species to be selected was Aster lanceolatus Willd., commonly known as the panicled aster, tall white aster or white field aster (LORENZI; SOUZA, 1995), which presents antibacterial activity against Streptococcus pyogenes, Salmonella typhimurium and Staphylococcus aureus (DIAS et al., 2005, 2006); fungicidal activity against Fusarium oxysporum and Cylindrocladium spathulatum (DIAS et al., 2006); and allelopathy against germination and growth of Lactuca sativa (DIAS et al., 2007).

The second species to be selected was Chamomilla recutita (L.) Rauschert, commonly known as camomile, since this is the most widely cultivated and most popular herb among small farmers in Brazil. It presents carminative, antispasmodic, and anti-inflammatory properties (RAMOS et al., 2004), as well as being recommended as a vermicide (SALOMON, 1992).

The third species chosen was Vernonia scabra Pers., commonly known as ironweed, because of its presence in the regular diet of ruminants in the interior of Brazil (COSTA et al., 2006).

Thus, in this paper, we present our investigation on phytotherapeutic alternatives for controlling parasitism in sheep by means of in vitro parasite egg hatchability.

\section{Materials and Methods}

\section{Plant material}

The selected species were gathered from different areas, according to their natural distribution and local availability. The material collected was identified in conformity with the standards of classical taxonomy, based on floral morphological characters and using several samples, whenever possible. The species $A$. lanceolatus was collected in the city of Holambra, São Paulo, in June 2003, and was registered under number 287063 at the Municipal Botanical Museum of Curitiba; $C$. recutita was collected in the city of Mandirituba, Paraná, in April 2004; and V. scabra was collected in the SESC Private Natural Heritage Reserve, in the Pantanal region of Mato Grosso, in June 2002, and was registered under number 46141 at the herbarium of the Department of Botany, Universidade Federal do Paraná.

\section{Extract and oil collection}

To prepare the extracts and oils, the species were subjected to dissection in a heater, at a temperature of $40{ }^{\circ} \mathrm{C}$, for 24 to 48 hours. They were then kept in a dry place, away from direct sunlight and at temperatures ranging from 5 to $15^{\circ} \mathrm{C}$, until use, when they were ground up and weighed.

The C. recutita seeds ( $148.94 \mathrm{~g}$ ) were subjected to extraction in a modified Soxhlet apparatus (CARVALHO, 2009) with hexane, obtaining an oil fraction of $19 \%$. The aromatic oil consisted of the oil retained in the condensation water during the hydrodistillation process on aerial parts of the $C$. recutita plant, which presented an output of $0.25 \%$. The oils were used in the hatchability test without dilution.
The flowers $(560 \mathrm{~g})$ and the stems and leaves $(800 \mathrm{~g})$ of A. lanceolatus were subjected to extraction in a modified Soxhlet apparatus (CARVALHO, 2009) with ethanol $96^{\circ} \mathrm{GL}$. After extraction, the total volume of each of the products obtained was measured and then condensed in a rotary evaporator at reduced pressure, at a temperature of $50^{\circ} \mathrm{C}$ and rotation speed of $90 \mathrm{rpm}$, with filtration under vacuum, to produce concentrates known as crude extracts $(\mathrm{CE})$. These extracts $(1 \mathrm{~mL})$ were dried up and rendered soluble in $5 \%$ ethanol for use in the hatchability test.

The aerial parts of $V$. scabra $(100 \mathrm{~g})$ were subjected to aqueous extraction by means of heat maceration. After extraction, the resultant extract was filtered in cotton, to produce an aqueous extract that was used in the hatchability test.

The filtered extract products were subjected to dry residue determination, in which $1 \mathrm{~mL}$ of extract to be analyzed was placed in a weighed pan and then heated at $100^{\circ} \mathrm{C}$ until constant weight was achieved (DIAS, 2005). The result was shown as the amount of solids in $1 \mathrm{~mL}$. We obtained $0.0785,0.0475$ and $0.1022 \mathrm{~g} \cdot \mathrm{mL}^{-1}$ of dry residue for the extracts of flowers, stems and leaves from A. lanceolatus and for the aerial parts of $V$. scabra, respectively.

\section{Obtainment of helminth eggs}

The method used was the modified method proposed by the World Association for the Advancement of Veterinary Parasitology (WAAVP) (COLES et al., 1992).

To obtain helminth eggs for testing with the plant samples, sheep feces containing eggs were used. These eggs had the typical morphological characteristics of eggs produced by the superfamily Strongyloidea, family Trichostrongylidae, in accordance with the modified method of Gordon and Whitlock (UENO; GUTIERRES, 1983).

The feces were collected directly from the rectal ampulla and were kept at room temperature. The material was homogenized using a hypersaturated saline solution, filtered in mesh sieves of 180 and $250 \mathrm{mn} . \mu \mathrm{m}^{-1}$, and then centrifuged at $2000 \mathrm{rpm}$ for two minutes. The supernatant material was transferred to another centrifuge recipient, and three consecutive washes with distilled water were performed. During the last wash, a small amount of distilled water was kept in the sediment, which was resuspended and transferred to test tubes in aliquots of $200 \mu \mathrm{L}$, containing approximately 1430 eggs.

\section{Hatchability test}

The method used for this stage was a modified version of the hatchability test to determine the efficiency of the anthelmintic, in accordance with Krychak-Furtado et al. (2005). The same amount to be tested was added to each test tube containing $200 \mathrm{~mL}$ of the egg solution. The tubes were incubated under saturated moisture in a heater at a temperature of $26 \pm 1^{\circ} \mathrm{C}$, for 72 hours. The time elapsed from collecting the feces to beginning the incubation of the eggs under the action of the plant extracts was two hours, at the most.

The influence of the samples on egg development was evaluated after incubation periods of 48 hours and 72 hours, by transferring 
Table 1. Average percentage inhibition of Trichostrongylidae eggs development in sheep and formation of larvae over 48 and 72 hours.

\begin{tabular}{|c|c|c|c|c|c|c|}
\hline \multirow[t]{2}{*}{ Sample } & \multicolumn{3}{|c|}{48 hours } & \multicolumn{3}{|c|}{72 hours } \\
\hline & Egg* & $\mathrm{Egg}^{* *}$ & Larvae & Egg* & Egg** $^{* *}$ & Larvae \\
\hline Water & $0.500^{\mathrm{a}}$ & $0.050^{\mathrm{a}}$ & $99.440^{\mathrm{d}}$ & $0.000^{\mathrm{a}}$ & $0.000^{\mathrm{a}}$ & $100.000^{d}$ \\
\hline Alcohol & $0.135^{\mathrm{a}}$ & $1.550^{\mathrm{a}}$ & $98.305^{\mathrm{d}}$ & $0.100^{\mathrm{a}}$ & $0.070^{\mathrm{a}}$ & $99.825^{d}$ \\
\hline Albendazole & $91.950^{c}$ & $8.045^{\mathrm{a}}$ & $0.000^{\mathrm{a}}$ & $74.645^{c}$ & $25.350^{\mathrm{ab}}$ & $0.000^{\mathrm{a}}$ \\
\hline A. lanceolatus ${ }^{\mathrm{s}}$ & $1.670^{\mathrm{a}}$ & $87.135^{d}$ & $7.695^{\mathrm{ab}}$ & $2.795^{\mathrm{ab}}$ & $58.795^{\mathrm{b}}$ & $38.410^{\mathrm{bc}}$ \\
\hline A. lanceolatus flowers & $91.850^{c}$ & $6.450^{\mathrm{a}}$ & $1.695^{\mathrm{a} 1}$ & $80.305^{c}$ & $11.370^{\mathrm{ab}}$ & $8.310^{\mathrm{ab}}$ \\
\hline C. recutita & $5.140^{\mathrm{a}}$ & $48.425^{b}$ & $46.205^{c}$ & $2.550^{\mathrm{ab}}$ & $22.445^{\mathrm{ab}}$ & $75.005^{\mathrm{cd}}$ \\
\hline Aromatic essence & $5.840^{\mathrm{a}}$ & $67.320^{c}$ & $26.830^{\mathrm{bc}}$ & $1.935^{\mathrm{a}}$ & $10.950^{\mathrm{ab}}$ & $87.115^{d}$ \\
\hline V. scabra & $63.700^{\mathrm{b}}$ & $31.080^{\mathrm{b}}$ & $5.210^{\mathrm{ab}}$ & $60.645^{b c}$ & $26.135^{\mathrm{ab}}$ & $13.220^{\mathrm{ab}}$ \\
\hline
\end{tabular}

${ }^{\mathrm{sl}}=$ stems and leaves, $^{*}=$ blastomeres, ${ }^{* *}=$ larva eggs. Averages with the same letters in the same column were not different from each other in the Tukey test $(\mathrm{p}<0.05)$.

the samples from the test tubes to Petri dishes and making readings under an optical microscopic at a magnification of 100X. All eggs present in the samples were evaluated and classified according to the development stage at which they were found, i.e. blastomeres, larvae in eggs and larvae outside of eggs, and whether these larvae were mobile or not.

The procedure was performed in duplicate and repeated with distilled water, $70 \%$ ethanol diluted to $5 \%$ and albendazole sulfoxide, at a density of $136 \mathrm{mg} \cdot \mathrm{mL}^{-1}$, as the control for the tests. The results were expressed as percentages of inhibition and were subjected to statistical analysis using the SISVAR software (FERREIRA, 2000). Statistical differences were determined by means of the Tukey test and the statistical significance level was set at $\mathrm{p}<0.05$.

\section{Results and Discussion}

For an anthelmintic treatment to be considered efficient in a hatchability test, it needs to modify the normal development of the eggs, through stopping them from hatching or inhibiting the emergence of first stage larvae. Thus, the greater the percentage of blastomeres observed over the period evaluated, the greater the efficiency of the treatment will be.

With regard to the duration of the observations, all previous investigations were done over only a 48-hour period, and the evolution was halted through addition of Lugol's iodine at the time of making the readings. In the present experiment, the observations were continued until reaching 72 hours, without interruption of the larval evolution. For this reason, in the present study, it was sought to identify extracts that, although effective over a 48-hour period, would also enable evolution to occur over the next 24 hours, i.e. such that these extracts would not inhibit but would only delay egg development. This study would also make it possible to observe any occurrence of the opposite effect, i.e. identifying extracts that would allow larval development over a 48-hour period, but would impede hatching over a 72-hour period. Thus, as stated by Batista et al. (1999), delayed hatching and the action of the extract on the larvae might result in making all eggs laid by the parasite nonviable.

Table 1 displays the results obtained. It can be seen from this that the essential oil of $C$. recutita (hydrolate) did not present satisfactory results, given that it allowed approximately $27 \%$ of the eggs to hatch within 48 hours. At the 72-hour reading, $87 \%$ of the larvae had hatched. Treatment of Trichostrongylidae eggs from sheep with an aqueous extract from $V$. scabra showed that this plant was capable of inhibiting egg development by around $61 \%$, as observed after 48 and 72 hours. This result is greatly superior to the results found by Alawa et al. (2003), thus suggesting that there is a need for more detailed study on this genus, since two of its species appear to be promising for anthelmintic treatment. However, among the three species, ovicide properties similar to those of albendazole were observed over 72 hours.

Conflicting results for the same experiment were found by Costa et al. (2002) when working with ethanol extracts and Mangifera indica hexane extract: the first presented excellent ovicide activity, while the second presented none. In the same way, extracts obtained from the same species, but from different parts of the plant, also demonstrated very different effects. Our tests on A. lanceolatus stems and leaves (Table 1) showed that although the samples did not stop the formation of larvae, they inhibited hatching by $87 \%$. On the other hand, the extract obtained from flowers inhibited the formation of larvae by $91 \%$ over 48 hours, and similar manifestations were maintained over 72 hours, with results that were similar to those from albendazole.

Studies on this species have revealed that sitosterol is present in the flowers, stems and leaves, while spinasterol and kaempferol galactoside rhamnoside are present in its flowers (DIAS, 2005). The analysis on the essential oils produced from the flowers revealed thirteen components: myrtenol, muurolene, naphthalene, bisabolene, lanona, spathulenol, caryophyllene oxide, cyclohexene carboxaldehyde, cedrenol, neoclovene, azulene, benzocyclobutene and hexahydrofarnesyl acetone. Among these, the highest concentration is presented by caryophyllene oxide (DIAS et al., 2009). Thus, further studies on the extracts of $A$. lanceolatus should be conducted, with the purpose of determining their toxicity and safety for use in sheep flocks.

\section{Conclusion}

In this experiment, the activity levels of gross plant extracts were investigated with the objective of classifying the anthelmintic potential of the selected plants against Trichostrongylidae eggs development in sheep. Out of the three species tested, only the gross ethanol extract obtained from $A$. lanceolatus flowers presented 
efficient action on Trichostrongylidae eggs development in sheep. This study encourages further investigations on this species, as a means for parasite control in animals, or as a species to be cultivated commercially in order to support the herbal drug industry.

\section{Acknowledgements}

The authors would like to thank Universidade Tuiuti do Paraná and Universidade Federal do Paraná for allowing us to use their equipment, material and laboratories.

\section{References}

ALAWA, C. B. I. et al. In vitro screening of two Nigerian medicinal plants (Vermonia amygdalina e Annona senegalensis) for anthelmintic activity. Veterinary Parasitology, v. 113, n. 1, p. 73-81, 2003. http://dx.doi.org/10.1016/S0304-4017(03)00040-2

BATISTA, L. M. et al. Atividade ovicida e larvicida in vitro das plantas Spigelia anthelmia e Momordica charantia contra o nematódeo Haemonchus contortus. Ciência Animal, v. 9, n. 2, p. 67-73, 1999.

CARVALHO, J. L. S et al. Termoestabilidade de processos extrativos de Nasturtium officinale R. Br., Brassicaceae por sistema Soxhlet modificado. Química Nova, v. 32, n. 4, p. 1031-1035, 2009.

COLES, G. C. et al. World Association for the Advancement of Veterinary Parasitology (W.A.A.V.P.) methods for the detection of anthelmintic resistance in nematodes of veterinary importance. Veterinary Parasitology, v. 44, n. 1-2, p. 35-44, 1992. http://dx.doi. org/10.1016/0304-4017(92)90141-U

COSTA, C. T. C. et al. Efeito ovicida de extratos de sementes de Mangifera indica L. sobre Haemonchus contortus. Revista Brasileira de Parasitologia Veterinária, v. 11, n. 2, p. 57-60, 2002.

COSTA, S. S. et al. Plants composing the diet of marsh and pampas deer in the Brazilian Pantanal wetland and their ethnomedicinal properties. Journal of Biological Sciences, v. 6, n. 5, p. 840-846, 2006. http://dx.doi.org/10.3923/jbs.2006.840.846

CUNNINGHAM, A. B. Etnobotánica aplicada: pueblos, uso de plantas silvestres y conservación. Montevideo, Uruguay: World Wildlife Fund - WWF, 2001.

DIAS, J. F. G. Estudo alelopático aplicado de Aster lanceolatus, Willd. 2005. Dissertação (Mestrado em Ciências Farmacêuticas)Universidade Federal do Paraná, Curitiba, 2005.

DIAS, J. F. G. et al. Avaliação do efeito do extrato etanólico de Aster lanceolatus Willd. (Asteraceae) no controle do crescimento das bactérias da placa dentária. Estudo "in vitro". Visáo Acadêmica, v. 6, n. 2, p. 20-23, 2005.

DIAS, J. F. G. et al. Atividade antibacteriana e antifúngica de extratos etanólicos de Aster lanceolatus Willd.; Asteraceae. Brazilian Journal of Pharmacognosy, v. 16, n. 1, p. 83-87, 2006.

DIAS, J. F. G.; MIGUEL, O. G.; MIGUEL, M. D. Cromatografia gasosa e avaliação da atividade alelopática das frações hexano, diclorometano e acetato de etila de Aster lanceolatus Willd. (Asteraceae). Visáo Acadêmica, v. 8, n. 2, p. 11-19, 2007.

DIAS, J. F. G.; MIGUEL, O. M.; MIGUEL, M. D. Composition of essential oil and allelopathic activity of aromatic water of Aster lanceolatus
Willd. (ASTERACEAE). Brazilian Journal of Pharmaceutical Sciences, v. 45, n. 3, p. 469-474, 2009. http://dx.doi.org/10.1590/S198482502009000300012

ECHEVARRIA, F. A. M. et al. The prevalence of anthelmintic resistance in nematode parasites of sheep in Southern Latin America: Brazil. Veterinary Parasitology, v. 62, n. 3-4, p. 199-206, 1996. http://dx.doi. org/10.1016/0304-4017(95)00906-X

FERREIRA, D. F. Sistema de Análise de Variância de Dados Balanceados - SISVAR. Lavras: UFLA, 2000. Pacote computacional.

HERD, R. Impactos ambientais associados aos compostos endectocidas. In: PADILHA, T. Controle dos nematóides gastrintestinais em ruminantes. Coronel Pacheco: EMBRAPA-CNPGL, 1996. p. 95-111.

JACKSON, F. Anthelmintic resistance - the state of play. British Veterinary Journal, v. 149, n. 2, p. 123-138, 1993.

KRYCHAK-FURTADO, S. et al. Efeito de Carica papaya L. (Caricaceae) e Musa paradisiaca Linn (Musaceae) sobre o desenvolvimento de ovos de nematódeos gastrintestinais de ovinos. Arquivos do Instituto Biológico, v. 72, n. 2, p. 191-197, 2005.

LORENZI, H.; SOUZA, H. M. Plantas ornamentais no Brasil: arbustivas, herbáceas e trepadeiras. Nova Odessa: Editora Plantarum, 1995.

MARI, A.; FIEL, C. Enfermedades parasitárias de importáncia económica en bovinos. Uruguai: Editora Hemisfério Sur, 1992. 519 p

MELO, A. C. F. L et al. Nematódeos resistentes a anti-helmíntico em rebanhos de ovinos e caprinos do estado do Ceará, Brasil. Ciência Rural, v. 33, n. 2, p. 339-344, 2003.

RAMOS, C. I. et al. Resistência de parasitos gastrintestinais de ovinos a alguns anti-helmínticos no estado de Santa Catarina, Brasil. Ciência Rural, v. 32, n. 3, p. 473-477, 2002.

RAMOS, M. B. M. et al. Produção de capítulos florais da camomila em função de populaçóes de plantas e da incorporação ao solo de camade-aviário. Horticultura Brasileira, v. 22, n. 3, p. 566-572, 2004. http://dx.doi.org/10.1590/S0102-05362004000300013

SALOMON, I. Chamomile: a medicinal plant. The herb, spice and medicinal plant. Digest. Amherst, v. 10, p. 1-4, 1992.

UENO, H.; GUTIERRES, V. C. Manual para diagnóstico das helmintoses de ruminantes. Porto Alegre: Universidade Federal do Rio Grande do Sul, 1983.

VAN WYK, J. A.; MALAN, F. S. Resistance of field strains of Haemonchus contortus to ivermectin, closantel, rafoxanide and the benzimidazoles in South Africa. The Veterinary Record, v. 123, n. 9, p. 226-228, 1988. PMid:3176284. http://dx.doi.org/10.1136/vr.123.9.226

VIEIRA, L. S. Produçáo orgânica de ovinos: o controle de verminose. Associacao dos Criadores de Caprinos e Ovinos da Bahia - ACCOBA. Disponível em: <http://www.accoba.com.br/ap_info_dc.asp?idInfo=38 4\&idCategoria=5>. Acesso em: 25 out. 2004.

WALLER, P. J. The development of anthelmintic resistance in ruminant livestock. Acta Tropica, v. 56, n. 2-3, p. 233-243, 1994. http://dx.doi. org/10.1016/0001-706X(94)90065-5

WALLER, P. J. et al. Anthelmintic resistance in nematode parasites of sheep: learning from the Australian experience. The Veterinary Record, v. 136, n. 16, p. 411-413, 1995. PMid:7625057. http://dx.doi. org/10.1136/vr.136.16.411 